\title{
Investigating the correlation between commitment, spirituality and performance in workplace
}

\author{
Utik Bidayati \& Adi Hardianto \\ Universitas Ahmad Dahlan, Yogyakarta, Indonesia
}

\begin{abstract}
This study aims to assess the correlations between commitment and spirituality dimensions in the workplace of a supermarket and determine the effect of both dimensions in employee performance. The research form is a survey research using questionnaires as an instrument to obtain data. A questionnaire was developed and distributed to 104 permanent workers of a store. Confirmatory Factor Analysis (CFA) was used to test the validity of the conceptual model and multiple regression analysis was conducted to measure the correlations that lie within the model. The study revealed the correlation between organizational commitment and spirituality in workplaces of this store. The results showed that organizational commitment variable (X1) had no effect on employee performance. Meanwhile, variables of spirituality in the workplace (X2) affect the performance of employees.
\end{abstract}

Keywords: commitment, spirituality, performance

\section{INTRODUCTION}

Nowadays, organizations face great challenges to win the competition. The ability to run the organization efficiently and effectively, by maximizing the function and utilization of work tools, funds or financial assets, as well as the human resource management, is a measurement of organizational performance. Outstanding organizational performance gives the company a competitive advantage in competing and helping to win the competition. Human resources as an organizational resource have diverse roles that can improve organizational performance. Some researchers claim, from the perspective of one's psychological behavior, a correlation between human resource management practices with competitive advantages (Schuleer \& Jackson 1987, Schuler \& MacMillan 1984). Thereby, improving the performance of human resources is one way that companies can do to enhance organizational performance.

Organizations that want to enhance organizational performance, will always try to develop their diverse resources, including improving the performance of human resources. The performance arises because of the various drivers of an individual. This study aims to determine the influence of worker spirituality and commitment to the employee performance. Confidence in the values that the organization has which is part of the form of the one's spirituality level is widely seen in a leader. Several studies have shown that the value of spirituality that one believes will affect the ability to work.

\subsection{Commitment}

Organizations are always willing to hire employees who are loyal and committed to doing their work. Commitment to the organization is a form of trust and acceptance of organizational goals and values that lead to the desire to remain part of the organization. Commitment to the organization relates to intention to persist, or in other words loyal attitude to the organization (Luthans 1998).

The organizational commitment will have a positive and significant impact on performance. Employees are willing to persist and devote themselves to achieve work goals because they have the same values and goals in the organization (Hueryren \& Hong 2012). Several studies have shown that, organizational commitment has a significant positive effect on employee performance (Ghorbanpour et al. 2014).

H1: Employee commitment will result in good performance for the organization 


\subsection{Spirituality}

Developments in the organization environment also raise a variety of factors that can encourage the improvement of organizational performance. The issue of spirituality is increasingly growing and prominent in the organization. This sense of spirituality provokes some questions about the choices we make in our lives, including how we perceive our work (Howard 2002). When in the workplace, a worker who respects and adores spiritual attitude often confronts with organizational rules. In some organizations, human resources are still seen as a tool in achieving the company's goal of earning the material as the ultimate goal. Managers are required to be able to control their employees including in carrying out his spiritual attitude.

On the other hand, the strength of the organization values becomes more attractive for employees. Workplace spirituality has been defined as "the framework of organizational values that is evidenced in a culture that generates the experience of employee transcendence through work processes, facilitates a sense of being connected with others in a way that gives a feeling of completeness and happiness (Giacalone \& Jurkiewicz 2003). Some growing organizations are nurturing spirituality in their corporate strategy and culture (Kolodinsky et al. 2008).

Organizations that recognize the existence of spirituality in the workplace will see the workplace as a place inhabited by people with common sense and spirit, and believe that the development of spirit is as important as the development of the mind (Ashmos \& Duchon 2000). Workplace spirituality is one type of psychological climate, where workers perceive themselves as having an internal life that is preserved with meaningful work and placed within the context of a community in the workplace (Duchon \& Plowman 2005).

A work unit with a high spiritual level can be expected to experience higher performance. While those who adore the spiritual qualitative way of thinking make the treasure as an instrument for the achievement of a nobler goal. The highest and most valuable meaning, in which people will be happy, lies precisely in the aspect of their spirituality (Zohar \& Marshall 2004).

H2: The employees' level of spirituality will produce a good performance for the organization.

\section{RESEARCH METHOD}

This research was quantitative research with survey research method. Survey method is a research method in which information or research data is collected from several samples (Zikmud 2003). The survey method used questionnaires and interviews in collecting data (Gay \& Diehl 1992). This method used decision-making techniques in the form of diverse questions in written and oral (Balley 1985).

Data collection was done by disseminating questionnaires to the respondents who became the research sample. By using purposive sampling technique where the respondent was chosen by certain criterion (Arikunto 2009), the chosen respondents were the employees of a supermarket. The employment period becomes the determinant of respondent criteria.

Respondents were workers with at least 2 years' employment period. After the period, respondents are expected to be able to understand the organization and show the employee's commitment better. Indicators used in data collection were developed from indicators to measure individual employee performance. There are six performance indicators (Robbins, 2006): 1) Quality of work, 2) Quantity of work, 3) Timeliness, 4) Effectiveness, 5) Interpersonal relations, 6) Independence.

The dimensions of commitment were measured using descriptions developed by Moday et al. (1982), Lincoln (1983) and Bashaw (1997) namely, 1) Strong beliefs as well as acceptance of organizational goals and values, 2) Readiness to work hard, 3) Strong desire to persist in organization, 4) Employee willingness, 5) Employee loyalty, 6) Employee pride.

While the spiritual dimension is developed from the instruments of Ashmos \& Duchon (2000), namely 1) Inner life, 2) Meaningful work, 3) Belonging to the community.

The collected data were tested for validity and reliability, before hypothesis testing. Instrument validity was measured using Confirmatory Factor Analysis (CFA) (Long 1983). Table 1 shows that from the CFA test with 35 statements prepared, there were 33 valid statements. Then, reliability testing was conducted on valid statements. The result of the reliability testing shows Cronbach's Alpha value of organizational commitment variable was 0.884 , and Cronbach's Alpha value of spirituality variable at workplace is 0.842 , Cronbach's Alpha value of performance variable is 0.880 . Thus it can be said that all measurements done were reliable, because all Cronbach's Alpha values exceeded 0.7. 
Table 1. Validity and Reliability Testing

\begin{tabular}{|c|c|c|c|c|}
\hline Point & $\begin{array}{l}\text { Organiza- } \\
\text { tional } \\
\text { Commit- } \\
\text { ment }\end{array}$ & $\begin{array}{l}\text { Spirituality } \\
\text { in work- } \\
\text { place }\end{array}$ & $\begin{array}{l}\text { Perfor- } \\
\text { mance }\end{array}$ & $\begin{array}{l}\text { Cronbach's } \\
\text { Alpha }\end{array}$ \\
\hline KO1 & $0.583^{* * *}$ & & & \multirow{11}{*}{0.884} \\
\hline KO2 & $0.600^{* *}$ & & & \\
\hline KO3 & $0.722 * *$ & & & \\
\hline KO4 & $0.811^{* *}$ & & & \\
\hline KO5 & $0.729^{* *}$ & & & \\
\hline KO6 & $0.669^{* *}$ & & & \\
\hline KO7 & $0.512 * *$ & & & \\
\hline KO8 & $0.594 * *$ & & & \\
\hline КO9 & $0.751^{* *}$ & & & \\
\hline KO10 & $0.849^{* *}$ & & & \\
\hline KO11 & $0.764 * *$ & & & \\
\hline STK1 & & $0.568^{* * *}$ & & \multirow{12}{*}{0.842} \\
\hline STK2 & & $0.199^{*}$ & & \\
\hline STK3 & & $0.425^{* * *}$ & & \\
\hline STK4 & & $0.780^{* * *}$ & & \\
\hline STK5 & & $0.480^{* * *}$ & & \\
\hline STK6 & & $0.459^{* * *}$ & & \\
\hline STK7 & & $0.725^{* *}$ & & \\
\hline STK8 & & $0.668^{* * *}$ & & \\
\hline STK9 & & $0.658^{* * *}$ & & \\
\hline STK10 & & $0.796^{* * *}$ & & \\
\hline STK11 & & $0.643^{* * *}$ & & \\
\hline STK12 & & $0.633^{* *}$ & & \\
\hline K1 & & & $0.571 * *$ & \multirow{11}{*}{0.880} \\
\hline K2 & & & $0.930^{* *}$ & \\
\hline K3 & & & $0.530^{* *}$ & \\
\hline K4 & & & $0.693 * *$ & \\
\hline K5 & & & $0.602^{* *}$ & \\
\hline K6 & & & $0.591^{* * *}$ & \\
\hline K7 & & & $0.666^{* * *}$ & \\
\hline K8 & & & $0.852^{* *}$ & \\
\hline K9 & & & $0.208^{*}$ & \\
\hline K10 & & & $0.685^{* *}$ & \\
\hline K11 & & & $0.774 * *$ & \\
\hline
\end{tabular}

Anova analysis showed that spirituality and commitment in work were able to improve participants' performance significantly $(\mathrm{F}=58.567, \mathrm{p}=0.000)$. Result of hypothesis testing by using multiple regression is shown in table 2 .

Table 2. Summary of regression analysis result

\begin{tabular}{lllll}
\hline Model & $\beta$ & Sig. & F & Sig. \\
\hline (Constant) & 1.385 & 0.000 & & \\
$\begin{array}{l}\text { Organizational Commit- } \\
\text { ment }\end{array}$ & -0.036 & 0.550 & 58.567 & 0.000 \\
$\begin{array}{l}\text { Spirituality in the work- } \\
\text { place }\end{array}$ & 0.707 & 0.000 & & \\
\hline
\end{tabular}

The summary of regression analysis results in Table
2 shows that hypothesis 1 is not supported by empirical data where there is no impact of the organizational commitment on respondent performance $(\beta=$ $0.036, p=0.550$ ). This result is not in line with some researches that have been done by some previous researchers. In hypothesis $\mathrm{H} 2$, the data processing results show spirituality has a positive effect on employee performance $(\beta=0.707, p=0.000)$.

\section{RESULTS AND DISCUSSIONS}

Hypothesis testing and analysis performed on employees' commitment of the organization in this study, indicating that the employees' commitment does not affect the employee's performance. These results are not in line with research conducted by Hueryren \& Hong (2012) and Ghorbanpour et al. (2014), where the employee's commitment to the organization has a positive effect on the employees' performance in the form of willingness of employees to serve the organization, because of the similarity in understanding the organization values and goals.

\section{CONCLUSION}

These results certainly compel re-analysis, because there is no research that proves worker commitment does not affect the employees' performance. In the analysis that has been done in the spirituality and discussed previously, it can be seen that workplace spirituality can affect the performance of an individual. This result is in line with research conducted by Duchon \& Plowman (2005), where psychological conditions in the internal lives of workers guarded by their work will be meaningful to the workplace. This research is also in line with the Zohar \& Marshall study result (2004), where spirituality becomes a source of happiness and very meaningful in achieving goals, including in work.

\section{REFERENCES}

Arikunto, S. 2010. Metodologi Penelitian. Yogyakarta: Bina Aksara.

Ashmos, D. P. \& Duchon, D. 2000. Spirituality at work a conceptualization and measure. Journal of Management Inquiry. 13 (3): 134-145.

Duchon.D, Plowman,D.A. 2005. Nurturing the Spirit at Work : Impact Work Unit Performance. The Leadership Quartely. 16: 807-833.

Gay,L.R., Diehl,P.L. 1992. Research Methods for Business and Management. Pennsylvania: Macmillan Publishing.

Giacalone, R. A. and C. L. Jurkiewicz. 2003. 'Toward a Science of Workplace Spirituality', in R. A. Giacalone and C. 
L. Jurkiewicz (eds.), The Handbook of Workplace Spirituality and Organizational Performance:189-208. Amonk New York: M.E. Sharpe.

Ghorbanpour, Z., Dehghan H. \& Heyrani, F. 2014. Investigating the effect of organization commitment on performance of auditors in the community of certified accountants. Interdisciplinary Journal of Contemporary Research in Business 5 (10):199-205.

Howard, S. 2002. A spiritual perspective on learning in the workplace. Journal of Managerial Psychology 17 (3): 230242.

Hueryren, Y. \& Hong. D. 2012. The Mediating Effect of Organizational Commitment on Leadership Type and Job Performance. The Journal of Human Resource and Adult Learning 8 (2): 131-142.

Kolodinsky, R. W., Giacalone, R. A., \& Jurkiewicz, C. L. (2008). Workplace value and outcomes: Exploring personal, organizational, and interactive workplace spirituality. Journal of Business Ethics 81(2): 465-480.

Long, J. Scott. 1983. Confirmatory Factor Analysis. Bloomington: Sage Publication.

Luthans, F. 1998. Organizational Behavior, $8^{\text {th }}$ ed, New York: McGraw Hill.

Schuler, R.S. \& Jackson.S.E. 1987. Linking competitive strategies with human resources management practices. Academy of Management Executive 1 (3): 207-291.

Schuler. R.S. \& MacMillan. 1984. Gaining competitive advantage through human resource management practices. Human Resources Management 23(3): 241-255.

Zikmund, W.G., Babin, B.J., Carr, J.C., \& Griffin, M. 2013. Business research methods. New York: McGraw-Hill.

Zohar, D. \& Marshall, I. 2004. Spiritual Capital. Bandung: Mizan. 